Jurnal Akuntansi \& Manajemen

Vol 13, No. 2 - 2018, 58-74

\title{
PENGARUH EARNINGS MANAGEMENT DAN TAX AVOIDANCE TERHADAP NILAI PERUSAHAAN DENGAN STRUKTUR KEPEMILIKAN SEBAGAI MODERATING VARIABLE PADA PERUSAHAAN KELOMPOK LQ 45 DI BEI TAHUN 2013-2016
}

\author{
Nurhanimah $^{1}$, Rita Anugerah ${ }^{2}$, Vince Ratnawati ${ }^{3}$ \\ 1,2,3 Jurusan Magister Akuntansi Fakultas Ekonomi Universitas Riau \\ Email:nurhanimah@ymail.com
}

\begin{abstract}
The purpose of this study was to determine the effect of earnings management and tax avoidance on firm value with ownership structure as a moderating variable. This research was conducted on companies registered in the LQ 45 index for the period 2013-2016 with a purposive sampling technique. Data analysis technique using WarpPLS version 5.0.

The results show that earnings management affects the value of the company, whereas tax avoidance does not affect the value of the company. Researcher also found managerial ownership does not moderated the relasionship between earnings management and tax avoidance on firm value. Institutional ownership moderates the of earnings management on firm value but does not moderates the relationship between tax avoidance on firm value.
\end{abstract}

Keywords: Firm's Value, Earnings Management, Tax Avoidance, Managerial Ownership and Institutional Ownership

Tujuan penelitian ini adalah untuk mengetahui pengaruh earnings management dan tax avidance terhadap nilai perusahaan dengan struktur kepemilikan sebagai moderating variable. Penelitian ini dilakukan pada perusahaan yang terdaftar dalam kelompok LQ 45 periode 2013-2016 dengan teknik purposive sampling. Teknik analisis data menggunakan WarpPLS versi 5.0.

Hasil peneitian menunjukkan bahwa earnings management mempengaruhi nilai perusahaan, sedangkan tax avoidance tidak mempengaruhi nilai perusahaan. Peneliti juga menemukan kepemilikan manajerial tidak memoderasi hubungan antara earnings management dan tax avoidance pada nilai perusahaan. Kepemilikan institusional memoderasi earnings management pada nilai perusahaan tetapi tidak memoderasi hubungan antara tax avoidance terhadap nilai perusahaan.

Kata kunci : $\quad$ Nilai Perusahaan, Earnings Management, Tax Avoidance, Kepemilikan Manajerial dan Kepemilikan Institusional 


\section{PENDAHULUAN}

Nilai perusahaan merupakan persepsi investor terhadap tingkat keberhasilan perusahaan yang sering dikaitkan dengan harga saham (Sujoko dan Soebiantoro, 2007). Harga saham yang tinggi membuat nilai perusahaan juga tinggi. Haruman (2008) menyatakan bahwa nilai perusahaan yang tinggi akan memiliki dampak terhadap kemakmuran pemegang saham, sehingga para pemegang saham menginvestasikan modalnya ke perusahaan tersebut. Nilai perusahaan yang tinggi akan membuat pasar percaya tidak hanya pada kinerja perusahaan saat ini, namun juga prospek perusahaan di masa depan.

Nilai perusahaan dapat diukur dengan beberapa aspek, salah satu ukuran yang digunakan untuk menilai perusahaan adalah dengan menggunakan rasio Tobin's Q. Rasio Tobin's Q menunjukkan performa manajemen dalam mengelola aset perusahaan. Nilai Tobin's Q menggambarkan kondisi peluang investasi yang dimiliki perusahaan atau potensi pertumbuhan perusahaan (Tobin (1969) dalam Sudiyatno dan Puspitasari, 2010). Rasio Tobin's Q merupakan salah satu alternative pengukuran kinerja perusahaan yang dapat digunakan dengan menggabungkan antara nilai buku dan nilai pasar ekuitas. Rasio ini diukur dari nilai pasar ekuitas ditambah nilai buku total kewajiban kemudian dibagi dengan nilai buku total asset (Hariati dan Rihatiningtyas, 2015).

Menurut Herawaty (2008) nilai perusahaan pada saat tertentu dapat ditingkatkan melalui earnings management (manajemen laba), dimana dalam dalam penyusunan laporan keuangan manajemen dapat mempengaruhi tingkat laba yang dihasilkan. Earnings management yang dilakukan manajemen perusahaan akan meningkatkan nilai perusahaan pada suatu waktu, lalu kemudian akan turun. Dengan demikian, ketika terjadi perilaku earnings management maka kualitas laba yang disajikan dalam laporan keuangan menjadi rendah dan tidak akurat, hal ini tentunya akan mengganggu keputusan investor di periode berikutnya dan dapat menurunkan nilai perusahaan.

Selain melakukan manajemen laba, keputusan keuangan yang dilakukan manajemen yang bisa mempengaruhi nilai perusahaan adalah melakukan tax avoidance (penghindaran pajak) (Lestari dan Ningrum, 2018). Tax avoidance adalah upaya penghindaran pajak yang dilakukan secara legal dan aman bagi wajib pajak karena tidak bertentangan dengan undang-undang dan peraturan perpajakan, dimana metode dan teknik yang digunakan cenderung memanfaatkan kelemahankelemahan (grey area) yang terdapat dalam undang-undang dan peraturan perpajakan itu sendiri untuk memperkecil jumlah pajak yang terhutang (Pohan, 2013).

Dalam prakteknya earnings managemen dan tax avoidance dapat diminimalisir dengan adanya pengawasan melalui mekanisme struktur kepemilikan (Herawati (2008) dan Haruman (2010)). Struktur kepemilikan dalam hal ini kepemilikan manajerial dan kepemilikan institusional. Kepemilikan manajerial merupakan kepemilikan saham oleh manajemen perusahaan yang diukur dengan persentase jumlah saham yang dimiliki oleh manajemen (Sujoko dan Soebiantoro, 2007). Dinyatakan oleh Kawatu (2009) bahwa ketika kepemilikan manajerial rendah, maka insentif terhadap kemungkinan perilaku oportunistik manajer akan meningkat. Dengan demikian diasumsikan ketika kepemilikan manajerial tinggi, maka akan mengurangi perilaku oportunistik manajer. Kepemilikan institusional adalah jumlah 
kepemilikan saham yang dimiliki institusi. Kepemilikan institusional mencakup bank, dana pensiun, perusahaan asuransi, dan lembaga-lembaga keuangan lainnya (Wardhani, 2008). Menurut Purwaningtyas (2011), semakin tinggi tingkat kepemiikan institusional, maka semakin kuat kontrol terhadap perusahaan. Hal ini sejalan dengan hasil penelitian Darwis (2012) yang menyatakan kepemilikan saham yang dimiliki oleh pihak institusional dapat memperlemah pengaruh earnings management terhadap nilai perusahaan. Cornet et.al. (2006) dalam Darwis (2012) menyatakan bahwa tindakan pengawasan perusahaan oleh pihak investor institusional dapat mendorong manajer untuk memfokuskan perhatiannya terhadap kinerja perusahaan sehingga mengurangi perilaku opportunistic atau mementingkan diri sendiri.

Penelitian tentang pengaruh earnings management terhadap nilai perusahaan telah dilakukan oleh Herawaty (2008) dan Ferdawati (2009). Hasil penelitian tersebut membuktikan earnings management berpengaruh terhadap nilai perusahaan. sedangkan Darwin (2012) dan Kamil (2014) membuktikan bahwa earnings management tidak berpengaruh terhadap nilai perusahaan.

Penelitian tentang tax avoidance terhadap nilai perusahaan telah dilakukan oleh Setiyaningsih (2018) dan Herdiyanto dan Ardiyanto (2015) hasil penelitian membuktikan tax avoidance berpengaruh terhadap nilai perusahaan. berbeda dengan hasil penelitian yang dilakukan oleh Wardhani (2018) dan Jonathan (2016) yang membuktikan bahwa tax avoidance tidak berpengaruh terhadap nilai perusahaan.

Adapun penelitian tentang struktur kepemilikan sabagai variabel moderasi hubungan antara earnings management dan tax avoidance terhadap nilai perusahaan telah dilakukan oleh Kamil (2014) membuktikan bahwa kepemilikan manajerial dan kepemilikan institusional memoderasi hubungan earnings management terhadap nilai perusahaan. Herawaty (2008) membuktikan kepemilikan manajerial tidak memoderasi hubungan earnings management terhadap nilai perusahaan. sedangkan Pamungkas (2012) membuktikan kepemilikan institusional tidak memoderasi hubungan earnings management terhadap nilai perusahaan. Penelitian Setiyaningsih (2018) dan Herdiyanto (2017) membuktikan kepemilikan institusional tidak memoderasi hubungan tax avoidance terhadap nilai perusahaan. Penelitian Sartika (2015) membuktikan kepemilikan institusional memoderasi hubungan tax avoidance terhadap nilai perusahaan.

Bersarkan penjelasan diatas dan penelitian terdahulu, peneliti tertarik melakukan penelitian dengan judul "Pengaruh Earnings management Dan Tax Avoidance Terhadap Nilai Perusahaan Dengan Struktur Kepemilikan Sebagai Moderating Variable".

\section{TELAAH PUSTAKA}

\section{Teori keagenan (agency theory)}

Perspektif hubungan keagenan merupakan dasar yang digunakan untuk corporate governance. Jensen dan Meckling (1976) menyatakan bahwa hubungan keagenan (agency relationship) adalah sebuah kontrak dimana satu atau lebih pemilik (prinsipal, dalam hal ini pemegang saham) memperkerjakan seseorang (agen) untuk melaksanakan pekerjaan untuk kepentingan mereka dengan cara mendelegasikan beberapa kebijakan dalam pengambilan keputusan. 


\section{Teori sinyal (signaling theory)}

Teori sinyal mengemukakan tentang bagaimana seharusnya sebuah perusahaan memberikan sinyal kepada pengguna laporan keuangan (Kusumawardani, 2011). Sinyal-sinyal tersebut salah satunya dapat berupa laporan laba/rugi yang dialami oleh perusahaan, beban atau biaya yang dikeluarkan perusahaan, atau data-data keuangan lainnya (Wahyudiono, 2014).

\section{Teori akuntansi positif (positive accounnting theory)}

Teori akuntansi positif berupaya menjelaskan sebuah proses, yang menggunakan kemampuan, pemahaman, dan pengetahuan akuntansi serta penggunaan kebijakan akuntansi yang paling sesuai untuk menghadapi kondisi tertentu di masa mendatang. Teori akuntansi positif pada prinsipnya beranggapan bahwa tujuan dari teori akuntansi adalah untuk menjelaskan dan meramalkan pilihan strandar dan prosedur akuntansi yang dipilih manajemen melalui analisis atas biaya dan manfaat dari pengungkapan keuangan tertentu dalam hubungannya dengan berbagai individu dan pengalokasian sumber daya ekonomi (Riahi dan Belkaoui, 2007)

\section{Nilai perusahaan}

Nilai perusahaan adalah persepsi investor mengenai tingkat kemakmuran pemegang saham yang berkaitan dengan harga pasar saham perusahaan (Sujoko dan Soebiantoro, 2007). Nurlela dan Islahuddin (2008) menjelaskan bahwa enterprise value (EV) atau dikenal juga sebagai firm value (nilai perusahaan) merupakan konsep penting bagi investor, karena merupakan indikator bagi pasar menilai perusahaan secara keseluruhan. Sukirni (2012) menjelaskan bahwa nilai perusahaan merupakan kondisi tertentu yang telah dicapai oleh suatu perusahaan sebagai gambaran dari kepercayaan masyarakat terhadap perusahaan setelah melalui kegiatan beberapa tahun, yaitu sejak perusahaan tersebut didirikan sampai dengan saat ini. Nilai perusahaan merupakan persepsi investor terhadap tingkat keberhasilan suatu perusahaan yang sering dikaitkan dengan harga saham. Harga saham yang tinggi membuat nilai perusahaan juga tinggi. Nilai perusahaan yang tinggi akan membuat pasar percaya tidak hanya pada kinerja perusahaan saat ini namun juga pada prospek perusahaan masa depan (Sujoko dan Soebiantoro, 2007)

\section{Earnings management}

Schipper (1989) mendefinisikan earnings management adalah suatu tindakan intervensi yang dilakukan manajemen dengan sengaja dalam proses penentuan laba, biasanya untuk memenuhi kebutuhan pribadi (Sulistyanto, 2008). Pendapat Davidson, Stickney, dan Weil dalam Sulistyanto (2008) yang menyatakan manajemen laba (Earnings management) merupakan suatu proses pengambilan langkah tertentu yang disengaja dalam batas Prinsip Akuntansi Berteruma Umum (PABU) untuk menghasilkan tingkat yang diinginkan dari laba yang dilaporkan. Definisi tersebut menunjukkan Earnings management sebagai aktivitas yang biasa dilakukan manajer dalam menyusun laporan keuangan. Upaya rekayasa manajerial ini dianggap lumrah dan bukan merupakan suatu pelanggaran atau kecurangan karena dilakukan dalam ruang lingkup prinsip akuntansi (Sulistyanto, 2008). 


\section{Tax avoidance}

Menurut Pohan (2013) tax avoidance merupakan upaya penghindaran pajak yang dilakukan secara legal dan aman bagi wajib pajak karena tidak bertentangan dengan ketentuan perpajakan, di mana metode dan teknik yang digunakan cenderung memanfaatkan kelemahan-kelemahan (grey area) yang terdapat dalam undangundang dan peraturan perpajakan itu sendiri, untuk memperkecil jumlah pajak yang terutang.

\section{Kepemilikan manajerial}

Kepemilikan manajerial adalah jumlah kepemilikan saham oleh pihak manajemen dari seluruh modal saham perusahaan (Boediono, 2005). Kepemilikan manajemen terhadap saham perusahaan dipandang dapat menselaraskan potensi perbedaan antara pemegang saham luar dengan manajemen, sehingga permasalahan keagenan diasumsikan akan hilang apabila seorang manajer adalah seorang pemilik juga (Yuono dan Widyawati, 2016). Dengan adanya kepemilikan manajerial maka manajer akan lebih termotivasi untuk meningkatkan kinerja perusahaan. hal ini kerena manajer merupakan salah satu pemilik perusahaan dan bukan hanya sebagai pihak eksternal yang dipekerjakan untuk memenuhi kepentingan pemilik perusahaan. Manajer memegang peranan penting keran manajer melaksanakan perencanaan, pengorganisasian, pengarahan, pengawasan serta pengambil keputusan (Sukirni, 2012).

\section{Kepemilikan institusional}

Institusional adalah kepemilikan saham yang dimiliki oleh pihak institusi, kepemilikan institusi mencakup bank, dana pensiun, perusahaan asuransi, lembagalembaga keuangan lainnya (Wardhani, 2008). Kepemilikan saham oleh investor institusional mempunyai kemampuan dan mengalaman yang baik dibidang bisnis dan keuangan, sehingga akan mendorong peningkatan efektivitas pengawasan kinerja manajemen, dimana fungsi pengendalian akan semakin efektif. Semakin besar kepemilikan saham oleh investor institusional, maka semakin besar kekuatan suara dan dorongan institusi keuangan dalam mengawasi manajemen, sehingga dapat mendisiplinkan kinerja manajer untuk bertindak memaksimalkan kesejahteraan pemegang saham dan memberikan dorongan yang lebih besar untuk mengoptimalkan nilai perusahaan (Haryono, dkk. 2015)

\section{Hipotesis}

Perumusan hipotesis dalam penelitian ini adalah:

$\mathrm{H}_{1}$ : Earnings Mangement Berpengaruh Terhadap Nilai Perusahaan

$\mathrm{H}_{2}$ : Tax Avoidance Berpengaruh Terhadap Nilai Perusahaan

$\mathrm{H}_{3}$ :Kepemilikan manajerial memoderasi pengaruh Earnings Mangement Terhadap Nilai Perusahaan

$\mathrm{H}_{4}$ : Kepemilikan manajerial memoderasi pengaruh Earnings Mangement Terhadap Nilai Perusahaan

$\mathrm{H}_{5}$ : Kepemilikan manajerial memoderasi pengaruh Tax Avoidance Terhadap Nilai Perusahaan

$\mathrm{H}_{6}$ : Kepemilikan manajerial memoderasi pengaruh Tax AvoidanceTerhadap Nilai Perusahaan 


\section{METODOLOGI PENELITIAN}

\section{Populasi dan sampel}

Populasi dari penelitian ini semua perusahaan yang terdaftar dalam Kelompok LQ 45 yang listing di BEI selama delapan semester berturut-turut yakni dari tahun 2013-2016. Pemilihan sampel dalam penelitian ini ditentukan dengan menggunakan Purposive Sampling yaitu pengambilan sampel yang dilakukan berdasarkan kriteria. Adapun kretianya adalah sebagai beriku:

a. Merupakan perusahaan yang termasuk dalam kelompok LQ 45 secara berturut-turut selama 8 semester dalam periode 2013-2016

b. Mempublikasikan laporan keuangan lengkap selama periode terpilih (20132016)

c. Memiliki data yang lengkap terkait dengan variabel-variabel yang digunakan dalam penelitian.

\section{Jenis dan Sumber Data}

Data yang digunakan dalam penelitian ini adalah data sekunder. Data sekunder merupakan data primer yang telah diolah lebih lanjut dan disajikan baik oleh pengumpul data primer atau oleh pihak lain, kemudian digunakan untuk diproses lebih lanjut (Ghozali, 2005). Data sekunder yang digunakan dalam penelitian ini berupa data laporan keuangan dan laporan keuangan tahunan/annual report perusahaan sampel pada periode 2013 sampai dengan 2016.

Data yang diperoleh adalah kombinasi antara data time series dengan data cross section. Data time series merupakan sekumpulan data dari suatu fenomena yang didapat dari beberapa interval/ periode waktu tertentu. Sedangkan data crosssection adalah sekumpulan data yang digunakan untuk meneliti suatu fenomena tertentu dalam satu kurun waktu saja (Ghozali, 2005). Sumber data penelitian diperoleh dari Pusat Informasi Pasar Modal (PIPM), Indonesian Capital Market Directory (ICMD), website resmi Bursa Efek Indonesia (www.idx.co.id) serta sumber data pendukung lainnya.

\section{Definisi operasional dan pengukuran variabel}

1. Variabel endogen

Nilai perusahaan adalah persepsi investor mengenai tingkat kemakmuran pemegang saham yang berkaitan dengan harga pasar saham perusahaan (Sujoko dan Soebiantoro, 2007). Rasio Tobins Q yang dihutung dengan rumus sebagai berikut (Mawati, dkk. 2017):

$$
Q=\frac{(\mathbf{M V E}+\mathbf{D})}{(\mathbf{E B V}+\mathbf{D})}
$$

Keterangan:

$\mathrm{Q} \quad=$ Nilai Perusahaan

MVE = Nilai pasar Ekuitas (Equity Market Value), Merupakan dari hasil perkalian harga saham penutupan (closing price) akhir tahun dengan jumlah saham yang beredar pada akhir tahun.

D = Nilai buku dari total hutang perusahaan

EBV = Nilai buku dari total Ekuitas 
2. Variabel eksogen

a. Earnings mangement

Schipper (1989) mendefinisikan earnings management adalah suatu tindakan intervensi yang dilakukan manajemen dengan sengaja dalam proses penentuan laba, biasanya untuk memenuhi kebutuhan pribadi (Subramayam, 2010). Menurut Dechow et. al. (1995) dalam Wardani \& Hermuningsih (2013), rumus menghitung discretionary accrual adalah sebagai berikut:

1. Menghitung total accrual

TACc $_{i t}=E B X T_{i t}-C_{F}$

Dimana:

TAcc $_{\text {it }}=$ Total Accrual perusahaan i pada periode $\mathrm{t}$

EBXT $_{\text {it }}=$ Laba perusahaan i sebelum pos-pos luar operasi yang dihentikan untuk periode $\mathrm{t}$

$\mathrm{CFO}_{\text {it }} \quad=$ Cash Flow from Operation perusahaan i untuk periode tetap

2. Menghitung non discretionary accrual

Untuk menghitung non discretionary accrual adalah sebagai berikut:

$$
N D A_{C c} c_{i t}=\alpha_{1} \frac{1}{T A_{i, t-1}}+\alpha_{2} \frac{\left(\Delta R E V_{i t}-\Delta R E C_{i t}\right)}{T A_{i, t-1}}+\alpha_{3} \frac{P P E_{i t}}{T A_{i, t-1}}+\varepsilon_{i t} \ldots(2)
$$

Dimana:

NDAccit $=$ Non discretionary Accrual perusahaan i pada periode $\mathrm{t}$

$\alpha(1-3)=$ Koefisien regresi

$\mathrm{TA}_{\mathrm{i}, \mathrm{t}-1}=$ Total asset untuk perusahaan i pada akhir tahun $\mathrm{t}-1$

$\triangle \mathrm{REV}_{\mathrm{it}} \quad=$ Perubahan dalam pendapatan untuk perusahaan i pada akhir tahun $\mathrm{t}$, dibagi total asset perusahaan i pada akhir tahun $\mathrm{t}-1$

$\Delta \mathrm{REC}_{\mathrm{it}}=$ Perubahan dalam piutang bersih untuk perusahaan $\mathrm{i}$ pada tahun $t$, dibagi total asset untuk perusahaan i pada akhir tahun $\mathrm{t}-1$

$\mathrm{PPE}_{\mathrm{it}} \quad=$ Asset tetap perusahaan $\mathrm{i}$ pada tahun $\mathrm{t}$ dibagi total asset perusahaan i pada akhir tahun t-1

$\varepsilon_{\text {it }} \quad=$ Error perusahaan i pada tahun $\mathrm{t}$

3. Menghitung discretionary accrual

Discretionary accrual diestimasi dengan cara sebagai berikut:

$D_{A C c_{i t}}=\frac{\left(T A c c_{i t}\right)}{T A_{i, t-1}}-N D A c c_{i t}$

b. Tax avoidance

Menurut Pohan (2013) tax avoidance merupakan upaya penghindaran pajak yang dilakukan secara legal dan aman bagi wajib pajak karena tidak bertentangan dengan ketentuan perpajakan, di mana metode dan teknik yang digunakan cenderung memanfaatkan kelemahan-kelemahan (grey area) yang terdapat dalam undangundang dan peraturan perpajakan itu sendiri, untuk memperkecil jumlah pajak yang terutang.

Sesuai dengan penelitian yg dilakukan oleh Wahab et.al (2012) alat ukur tax avoidance adalah ETR (Effective Tax Rate). ETR dihutung dengan rumus sebagai berikut:

$$
E T R=\frac{\text { Beban Pajak }}{\text { Laba Sebelum Pajak }}
$$


3. Variabel moderating

a. Kepemilikan manajerial

Menurut Boediono (2005) kepemilikan manajerial adalah jumlah kepemilikan saham oleh pihak manajemen dari seluruh modal saham perusahaan yang dikelola. Dalam penelitian ini diukur dengan persentase jumlah saham yang dimiliki pihak manajemen dari seluruh modal saham perusahaan yang beredar.

b. Kepemilikan institusiona

$$
\mathrm{K} M \mathrm{Mngr}=\frac{\text { Jumlah saham yang dimiliki manajemen }}{\text { Jumlah saham perusahaan yang beredar }} \times 100 \%
$$

Kepemilikan institusional merupakan proporsi pemegang saham yang dimiliki oleh pemilik institusi atau lembaga seperti perusahaan asuransi, bank, perusahaan investasi dan kepemilikan institusi lain, kecuali anak perusahaan dan institusi lain yang memiliki hubungan istimewa (perusahaan afiliasi dan perusahaan asosiasi) (Yuono dan Widyawati, 2016). Kepemilikan institusional dihitung dengan cara sebagai berikut:

$$
\text { KInst }=\frac{\text { Jumlah saham institusi dan Perusahaan lain }}{\text { Jumlah saham perusahaan yang beredar }} \times 100 \%
$$

\section{Metode analisis data}

\section{Statistik deskriptif}

Statistik deskriptif memberikan gambaran atau deskripsi suatu data yang dilihat dari rata-rata (mean), standar deviasi, varian, maksimum dan minimum, sum, range, kurtosis dan skewness (Ghozali, 2012).

\section{Analisis partial least square}

Pengujian pada penelitian ini dilakukan dengan pendekatan Structural Equation Model (SEM) dengan menggunakan software Partial Least Square (PLS) yaitu software warpLS versi 5.0. PLS merupakan metoda SEM berbasis varian yang didesain untuk menyelesaikan persoalan yang tidak dapat dilakukan oleh CB-SEM seperti jumlah sampel kecil, data tidak berdistribusi normal secara multivariate, adanya missingvalues, dan adanya masalah multikolinieritas antar variabel eksogen (Latan dan Ghozali, 2014).

Latan dan Ghozali (2014) menyatakan bahwa SEM-PLS sering disebut juga soft modeling karena meniadakan asumsi-asumsi regresi OLS (Ordinary Least Square) seperti data harus berdistribusi normal secara multivariate dan tidak adanya masalah multikolinieritas antar variable independen (eksogen).

\section{HASIL DAN PEMBAHASAN}

\begin{tabular}{|c|c|c|c|}
\hline Variabel & Minimum & Maksimum & Rata-Rata \\
\hline Nilai Perusahaan & 0,64 & 4,04 & 1,64 \\
\hline Earnings Management & $-0,091$ & 0,111 & $-0,024$ \\
\hline Tax Avoidance & $-19,61$ & 45,32 & 25,54 \\
\hline Kepemilikan Manajerial & $0,001 \%$ & $15,12 \%$ & $1,29 \%$ \\
\hline Kepemilikan Institusional & $18,65 \%$ & $75,55 \%$ & $52,13 \%$ \\
\hline
\end{tabular}

Hasil statistik deskriptif

Suber: Data Olahan 2018 
Dari table 1 di atas diketahui bahwa variabel nilai perusahaan yang diukur dengan rasio tobin's q memiliki nilai tertinggi sebesar 4,04 dan nilai terendah sebesar o,64 serta nilai rata-rata sebesar 1,64. Earnings management nilai maksimum sebesar 0,111 dan nilai minimum sebesar -0,091. Pada variabel tax avoidance nilai maksimum adalah 45,32 dan nilai minimum sebesar -19,61 dengan nilai rata-rat 25,54. Kepemilikan manajerial nilai maksimum 15,12\% dan nilai minimum 0,001\% dengan rata-rata $1,29 \%$. Adapun variabel kepemilikan institusional nilai maksimum sebesar $75,55 \%$, nilai minimum $18,65 \%$ serta nilai rata-rata sebesar $52,13 \%$.

\section{Analisis Partial Least Square}

\section{Hasil evaluasi model pengukuran (outer model)}

Dalam pengujian outer modeluntuk data yang bersifat observe data dijadikan sebagai indicator formatif. Dalam mengevaluasi indicator formatif dilakukan dengan melihat indicator weight. Hasil outer model pada indicator yang bersifat formatif dapat dilihat pada table berikut:

Tabel 2. Hasil Pengujian Indicator Weight

\begin{tabular}{|l|c|c|c|c|c|c|c|c|}
\hline & NP & ETR & KM & KI & NP & Type & P value & VIF \\
\hline EM & 1.000 & 0.000 & 0.000 & 0.000 & 0.000 & Formative & 0.001 & $\begin{array}{c}<0.00 \\
1\end{array}$ \\
\hline ETR & 0.000 & 1.000 & 0.000 & 0.000 & 0.000 & Formative & 0.001 & $\begin{array}{c}<0.00 \\
1\end{array}$ \\
\hline KM & 0.000 & 0.000 & 1.000 & 0.000 & 0.000 & Formative & 0.001 & $\begin{array}{c}<0.00 \\
1\end{array}$ \\
\hline KI & 0.000 & 0.000 & 0.000 & 1.000 & 0.000 & Formative & 0.001 & $\begin{array}{c}<0.00 \\
1\end{array}$ \\
\hline NP & 0.000 & 0.000 & 0.000 & 0.000 & 1.000 & Formative & 0.001 & $\begin{array}{c}<0.00 \\
1\end{array}$ \\
\hline
\end{tabular}

Sumber: Hasil Olahan WarpPLS 5.0

Pada Tabel 2 di atas dapat dilihat bahwa tidak ada terdapat indikator variabel yang memiliki nilai VIF di atas nilai 3,3 dan nilai $P$ value $<0,05$ untuk semua indikator. Sehinggga dapat disimpulkan bahwa data formatif pada penelitiaan telah layak untuk diuji.

\section{Hasil evaluasi model struktural (inner model)}

a. Hasil pengujian koefision determinasi

Tabel 3. Hasil Pengujian $R$ - Squared

\begin{tabular}{|l|c|}
\hline \multicolumn{1}{|c|}{ Variabel Laten } & R-Square \\
\hline Nilai Perusahaan & 0.47 \\
\hline
\end{tabular}

Sumber: Hasil Olahan WarpPLS 5.0

Tabel 3 menunjukan bahwa variabel nilai perusahaan dapat dijelaskan oleh variabilitas earnings management dan tax avoidance yang dimoderasi oleh 
kepemilikan manajerial dan kepemilikan institusional sebesar 0,47 atau 47\%, sedangkan sisanya 53\% dijelaskan oleh variabel lain diluar model penelitian. Hal ini berarti pengaruh earnings management, tax avoidance, yang dimoderasi oleh kepemilikan manajerial dan kepemilikan institusional terhadap nilai perusahaan adalah model kuat karena nilai R-Square di bawah 0,70 namun berada di atas o,45.

\section{Model fit index}

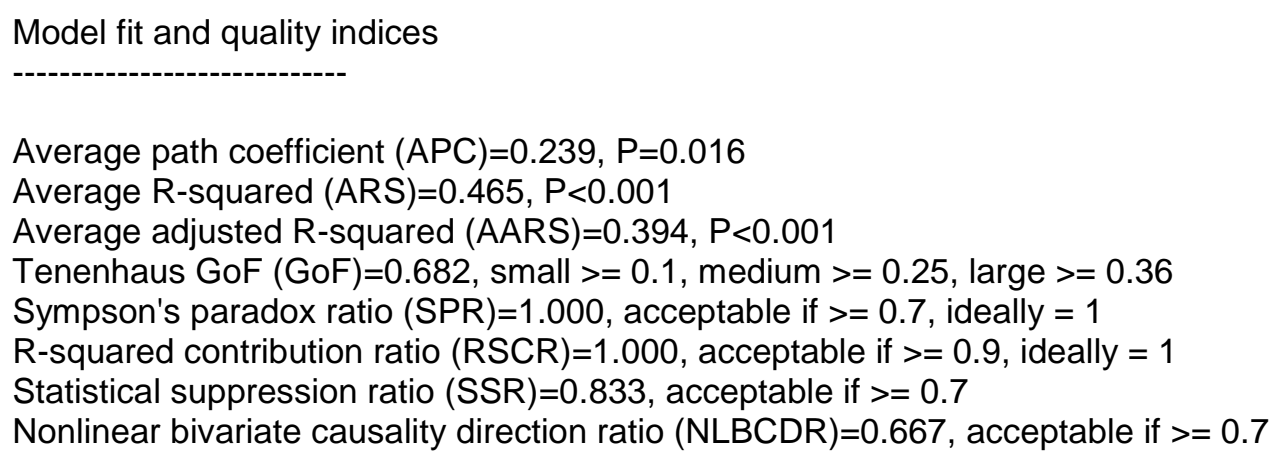

Sumber: Hasil Olahan WarpPLS 5.0

Gambar 1. Hasil pengujian model fit index

Pada Gambar 1 di atas, dapat dilihat bahwa nilai average path coefficient (APC) sebesar 0,239 dengan $p$-value $=0,016$, average $R$-squared (ARS) sebesar 0,465 dengan $p$-value $<0,001$, average adjusted $R$-squared (AARS) sebesar 0,394 dengan $p$-value $<0,001$. Untuk nilai average path coefficient (APC), average $R$-squared (ARS) dan average adjusted $R$-squared (AARS) memiliki nilai $p$-value di bawah 0,05. Artinya model pada penelitian ini telah memenuhi model fit indeks.

\section{HASIL PENGUJIAN HIPOTESIS DAN PEMBAHASAN Pengaruh earnings management terhadap nilai perusahaan}

Pada tabel 4.8 hasil pengujian hipotesis pertama menunjukkan bahwa earnings management berpengaruh terhadap nilai perusahaan, hal ini dapat dilihat dari koefisien jalur sebesar 0,61 memiliki nilai signifikan sebesar $p=0,01<0,05$. Dari pengujian hipotesis pertama dapat disimpulkan bahwa earnings management mampu mempangaruhi nilai perusahaan pada perusahaan kelompok LQ 45 yang terdaftar di BEI pada Tahun 2012-2016.

Pengaruh yang ditimbulkan earnings management terhadap nilai perusahaan adalah positif. Hal ini menunjukkan semakin besar manajer melakukan earnings management maka semakin tinggi nilai perusahaan. Hal ini berarti bahwa pihak manajemen perusahaan yang dipakai dalam sampel penelitian ini melakukan earnings management dalam rangka untuk menaikkan nilai perusahaan agar nilai perusahaan terlihat baik oleh investor.

Hasil penelitian ini sejalan dengan teori akuntansi positif yakni salah satu hal yang dapat memotivasi manajer untuk melakukan tindakan earnings management adalah bonus plan hypothesis. Menurut Watts dan Zimerman (1986) dalam Lestari dan Ningrum (2018) jika perusahaan merencanakan bonus berdasarkan net income maka perusahaan tersebut akan melakukan prosedur akuntansi yang menggeser pelaporan earnings masa mendatang ke periode sekarang. 
Hasil penelitian ini sejalan dengan hasil penelitian yang dilakukan oleh Ferdawati (2009), AT Marjani (2013) dan Abdallah dan Suryani (2018) yang membuktikan bahwa earnings management berpengaruh positif signifikan terhadap nilai perusahaan. Berbeda dengan hasil penelitian yang dilakukan oleh Herawaty (2008) dan Tanyawati (2012) membuktikan dalam penelitiannya bahwa earnings management berpengaruh negatif terhadap nilai perusahaan. Adapun penelitian yang dilakukan oleh Darwis (2012), Tamia, et.al. (2016) dan Kamil dan Hapsari (2014) membuktikan bahwa earnings management tidak berpengaruh terhadap nilai perusahaan.

\section{Pengaruh tax avoidance terhadap nilai perusahaan}

Pada table 4.9 hasil pengujian hipotesis kedua menunjukan bahwa nilai koefisien jalur sebesar -0,02 dengan $p-$ value $0,45>0,05$. Hasil penelitian yang diperoleh menjelaskan bahwa variabel tax avoidance tidak berpengaruh terhadap nilai perusahaan. Tarihoran (2016) menyatakan hal ini bisa terjadi karena kecenderungan investor untuk tidak melihat berapa besar pajak yang dibayarkan perusahaan sehingga tidak terlalu mempertimbangkan besarnya penghindaran pajak yang dilakukan oleh perusahaan. Investor pada umumnya lebih memilih menanamkan investasinya pada perusahaan yang labanya stabil atau tinggi. Maka dengan demikian, ada atau tidaknya tindakan tax avoidance pada perusahaan tidak mempengaruhi keputusan investor dalam melakukan investasi. Sehingga investor tidak akan menarik investasinya walaupun perusahaan melakukan tax avoidance atau tidak. Dengan demikian tidak ada dampak ada atau tidaknya tax avoidance terhadap nilai perusahaan.

Penelitian ini sejalan dengan penelitian yang dilakukan oleh Wardani dan Juliani (2018) dan Tarihoran (2016) bahwa tax avoidance tidak berpengaruh terhadap nilai perusahaan.

\section{Peran moderasi kepemilikan manajerial terhadap pengaruh antara earnings management dengan nilai perusahaan}

Pada table 4.10 hasil pengujian hipotesis ketiga menunjukan bahwa nilai koefisien jalur sebesar 0,07 dengan $p$-value 0,32 >0,05. Hasil pengujian tersebut dapat diambil kesimpulan bahwa kepemilikan manajerial tidak memoderasi hubungan antara earnings management terhadap nilai perusahaan. Penelitian ini mengindikasikan bahwa perusahaan dalam sampel tidak menggunakan kepemilikan manajerial untuk mengurangi tindakan earnings management.

Dalam prakteknya earnings managemen dapat diminimalisir dengan adanya pengawasan melalui mekanisme struktur kepemilikan (Herawati, 2008). Namun hasil penelitian ini menemukan bahwa kepemilikan manajerial sebagai mekanisme kontrol internal tidak dapat mengatur dan mengendalikan perusahaan untuk memberikan dan meningkatkan nilai perusahaan kepada pemegang saham. Hal ini karena perusahaan yang menjadi sampel penelitian sebagian besar proporsi kepemilikan manajerialnya rendah sehingga dimungkinkan manajer belum merasakan manfaat dari kepemilikan tersebut.

Penelitian ini konsisten dengan penelitian yang dilakukan oleh Herawaty (2008) dan Darwis (2012) yang menyatakan bahwa variabel kepemilikan manajerial tidak memoderasi hubungan earnings management terhadap nilai perusahaan. Lain 
halnya dengan penelitian yang dilakukan oleh Kamil dan Hapsari (2014) yang menemukan bahwa kepemilikan manajerial memoderasi hubungan earnings management terhadap nilai perusahaan.

\section{Peran moderasi kepemilikan institusional terhadap pengaruh antara earnings management dengan nilai perusahaan}

Pada 4.11 hasil pengujian hipotesis keempat menunjukkan bahwa kepemilikan institusional berpengaruh negatif signifikan terhadap pengaruh earnings management terhadap nilai perusahaan, hal ini dapat dilihat dari nilai koefisien jalur sebesar -0,41 dengan $p$-value 0,01<0,05. Hasil pengujian tersebut menunjukkan bahwa variabel kepemilikan instritusional mampu memperlemah pengaruh earnings management terhadap nilai perusahaan.

Hasil penelitian ini sejalan dengan temuan Herawaty (2008) bahwa earnings managemen dapat diminimalisir dengan adanya pengawasan melalui mekanisme struktur kepemilikan institusional. Dalam hal ini, investor institusional dapat mengontrol perusahaan dengan lebih teliti sehingga tindakan manajer melakukan earnings management dapat dikurangi. Shleiver dan Vishny (1986), Coffe (1991) dalam Siswantaya (2007), Ratnawati, Ali dan Popoola (2016) berpendapat bahwa kepemilikan institusional sangat berperan dalam mengawasi perilaku manajer dan membuat manajer untuk lebih berhati-hati dalam mengambil keputusan yang oportunis. Dengan lebih terkendalinya tindakan-tindakan yang dilakukan oleh manajerial, maka akan mempengaruhi kinerja perusahaan yang pada akhirnya akan berpengaruh terhadap nilai perusahaan.

Menurut Vishny (1997), Allen, Bernardo dan Welch (2000) kepemilikan institusional yang lebih besar akan lebih baik dalam memonitor perusahaan dibandingkan dengan kepemilikan institusional yang lebih kecil (Ratnawati, Ali dan Popoola (2015)). Disamping itu karakteristik dari investor institusional juga dapat mempengaruhi praktik earnings management (Ratnawati, Ali dan Popoola (2015)). Menurut Chen, Harford dan Li (2007) ada dua tipe dari investor institutional yaitu investor institusional jangka panjang dan jangka pendek. Investor jangka panjang akan lebih baik dalam memonitor. Hasil penelitian ini mengindikasikan kemungkinan investor pada perusahaan sampel adalah investor jangka pendek.

Penelitian ini konsisten dengan penelitian yang dilakukan oleh Herawaty (2008) dan Darwis (2012) yang menyatakan bahwa variabel kepemilikan institusional memoderasi hubungan earnings management terhadap nilai perusahaan. namun bertentangan dengan penelitian yang dilakukan oleh Pamungkas (2014) yang menemukan bahwa kepemilikan institusional tidak memoderasi hubungan earnings management terhadap nilai perusahaan.

\section{Peran moderasi kepemilikan manajerial terhadap pengaruh antara tax avoidance dengan nilai perusahaan}

Pada 4.12 hasil pengujian hipotesis menunjukan bahwa nilai koefisien jalur sebesar -0,14 dengan $p$-value 0,15>0,05. Hasil pengujian tersebut berarti bahwa kepemilikan manajerial tidak memoderasi hubungan antara tax avoidance terhadap nilai perusahaan.

Hasil penelitian ini menemukan bahwa kepemilikan manajerial sebagai mekanisme kontrol internal tidak dapat mengatur dan mengendalikan perusahaan untuk memberikan dan meningkatkan nilai perusahaan kepada pemegang saham. Hal 
ini karena perusahaan yang menjadi sampel penelitian sebagian besar proporsi kepemilikan manajerialnya rendah sehingga dimungkinkan manajer belum merasakan manfaat dari kepemilikan tersebut. Selain itu proporsi kepemilikan manajerial dalam perusahaan sampel lebih kecil dibandingkan dengan saham yang dimiliki oleh pihak institusional, sehingga membuat pihak manajemen tidak memiliki hak yang cukup besar dalam memberikan wewenang dan pengambilan keputusan. Hal ini bertentangan dengan pernyataan Haruman (2010) yang menyatakan tax avoidance dapat diminimalisir dengan adanya pengawasan melalui mekanisme struktur kepemilikan.

Hasil penelitian ini sejalan dengan penelitian yang dilakukan oleh Nike (2014) dan K. Andis (2016) yang menyatakan bahwa variabel kepemilikan manajerial tidak memoderasi hubungan tax avoidance terhadap nilai perusahaan. Namun berbeda dengan hasil penelitian Kusumayani (2017) yang menyatakan kepemilikan manajerial memoderasi hubungan tax avoidance terhadap nilai perusahaan.

\section{Peran Moderasi Kepemilikan Institusional Terhadap Pengaruh Antara Tax Avoidance Dengan Nilai Perusahaan}

Pada table 4.13 hasil uji hipotesis keenam menunjukan bahwa variabel kepemilikan institusional tidak memoderasi hubungan tax avoidance terhadap nilai perusahaan. hal ini dapat dibuktikan dari hasil uji hipotesis yang menunjukkan nilai koefisien jalur sebesar -0,19 dengan $p$-value 0,07>0,05.

Temuan ini berlawanan dengan hasil yang ditemukan oleh Desai dan Dharmapala (2005) dan Chen, dkk (2013). Mereka menemukan bahwa tata kelola perusahaan yang baik akan mempengaruhi hubungan antara penghindaran pajak (tax avoidance) dengan nilai perusahaan. meraka menjelaskan bahwa tata kelola perusahaan yang baik akan menjadi kamuflase bagi manajer dalam melakukan tax avoidance. Hal ini karena investor di Indonesia tidak ikut campur ke dalam urusan perpajakan perusahaan dengan kata lain investor institusional kurang mengontrol tentang kebijakan perpajakan yang dilakukan oleh perusahaan. Investor institusi hanya menginginkan pengembalian optimal atas dana yang telah diinvestasikan melalui peningkatan nilai perusahaan.

Menurut Chen, Harford dan Li (2007) ada dua tipe dari investor institutional yaitu investor institusional jangka panjang dan jangka pendek. Investor jangka panjang akan lebih baik dalam memonitor. Hal ini kemungkinan disebabkan karena investor pada perusahaan sampel adalah investor jangka pendek.

Hasil penelitian ini sejalan dengan penelitian yang dilakukan oleh Setiyaningsih (2018) dan Herdiyanto dan Ardiyanto (2015) yang menemukan bahwa kepemilikan institusional tidak memoderasi hubungan tax avoidance terhadap nilai perusahaan.

\section{KESIMPULAN DAN SARAN Kesimpulan}

Penelitian ini bertujuan untuk mengetahui pengaruh dari earnings management dan tax avoidance terhadap nilai perusahaan dengan variabel struktur kepemilikan dalam hal ini kepemilikan manajerial dan kepemilikan institusional sebagai variabel moderating. Berdasarkan hasil pengujian hipotesis dengan menggunakan aplikasi warpPLS 5.0, maka penulis dapat menyimpulkan sebagai berikut : 
1. Earnings management berpengaruh terhadap nilai perusahaan. Hal ini berarti semakin besar perusahaan melakukan earnings management maka semakin tinggi pula nilai perusahaan.

2. Tax Avoidance tidak berpengaruh terhadap nilai perusahaan. Hal ini berarti tidak ada dampak akibat dari ada atau tidaknya tax avoidance terhadap nilai perusahaan, sehingga tidak mempengaruhi investor dalam melakukan keputusan investasi.

3. Kepemilikan manajerial tidak memoderasi hubungan earnings management dan tax avoidance terhadap nilai perusahaan. hal ini berarti kepemilikan manajerial sebagai mekanisme kontrol internal tidak mampu mengendalikan dan mengatur perusahaan dalam memberikan dan meningkatkan nilai perusahaan.

4. Kepemilikan institusional memoderasi dalam hal ini memperlemah hubungan earnings management terhadap nilai perusahaan. Hal ini berarti pihak institusi dapat mengendalikan perusahaan dengan lebih teliti sehingga tindakan earnings management dapat dikurangi.

5. Kepemilikan institusional tidak memoderasi hubungan tax avoidance terhadap nilai perusahaan. sebagaimana dinyatakan Chasbiandani dan Martani (2012) hal ini karena pemegang saham, sebagai pengawas menyetujui tindakan tax avoidance yang dilakukan manajemen ketika keuntungan lebih besar dibandingkan dengan biaya yang dikeluarkan.

\section{Saran}

Berdasarkan kesimpulan dalam penelitian di atas, maka saran yang dapat disampaikan oleh peneliti antara lain:

1. Oleh karena earnings management berpengaruh terhadap nilai perusahaan, maka para pengguna informasi dari laporan keuangan maupun annual report perusahaan disarankan untuk berhati-hati dalam mengambil keputusan investasi. Karena laporan keuangan yang disajikan tidak menggambarkan keadaan yang sebesarnya yang mengakibatkan pengguna informasi salah menilai perusahaan tersebut telah dikelola dengan baik.

2. Kepemilikan manajerial perlu ditingkatkan agar pihak manajemen merasa perusahaan juga miliknya sehingga dapat mengurangi perilaku oportunistik manajer.

3. Perusahaan harus memisahkan antara kepemilikan institusional berdasarkan karakteristiknya yakni kepemilikan institutional jangka pendek dan kepemilikan institusional jangka panjang.

4. Penelitian selanjutnya dapat dilakukan dengan menambahkan variabel lain yang diduga dapat mempengaruhi nilai perusahaan, serta memperluas cakupan populasi dan sampel yang digunakan.

\section{UCAPAN TERIMAKASIH}

Alhamdulillaahirobbil'aalamiin, segala puji dan syukur bagi Allah Robb alam semesta yang telah memberikan kesehatan, kesempatan dan hidayah-Nya kepada penulis, sehingga penulis dapat menyelesaikan tesis ini. Dalam menujudkan tesis ini tidak luput dari bantuan dan bimbingan dari berbagai pihak. Oleh karena itu, dalam kesempatan ini penulis ingin menyampaikan ucapan terimakasih kepada:

1. Bapak Prof. Dr. H. Zulkarnain, SE,MM selaku Direktur Program Pascasarjana Universitas Riau 
2. Bapak Dr. H. M. Rasuli, SE, M.Si, Ak, CA selaku Ketua Prodi Studi Magister Akuntansi Program Pasca Sarjana Universitas Riau

3. Ibu Dr. Hj. Rita Anugerah, SE, MAFIS, Ak, CA selaku Dosen Pembimbing I dan Ibu Dr. Vince Ratnawati, SE, M.Si, Ak, BKP, CA selaku Dosen Pembimbing II yang telah bersedia meluangkan waktu dan dengan sabar memberikan pengarahan sehingga penulis dapat menyelesaikan tesis ini.

4. Bapak dan Ibu Dosen serta Staff Administrasi Program Studi Magister Akuntansi Program Pascasarjana Universitas Riau yang telah memberikan pengetahuan dan pelayanan selama penulis menimba ilmu di Program Studi Magister Akuntansi Program Pascasarjana Universitas Riau.

5. Ayah dan Ibu tercinta Suami dan buah hati penulis beserta kakak-kakak, abang, dan adik-adik yang penulis sayangi, yang telah memberikan motivasi dan segenap kasih sayang, cinta, doa, dan bantuan demi keberhasilan penulis.

6. Teman-teman magister akuntansi angkatan 15 terimakasih atas motivasi dan persahabatan kita selama ini.

7. Seluruh pihak yang telah membantu penyusunan sekripsi ini, namun tidak dapat penulis sebutkan satu persatu.

Semoga segala kabaikan dan keikhlasan yang telah diberikan kepada penulis mendapat limpahan pahala dari Allah SWT. Sekali lagi penulis sampaikan bahwa penulisan tesis ini tidak luput dari kesalahan dan kekurangan, oleh karena itu penulis mengharapkan kritik dan saran yang membangun demi kesempurnaan tesis ini.

Akhirnya penulis berserah diri kepada Allah SWT semoga tesis ini bermanfaat bagi penulis khususnya dan pembaca pada umumnya. Amiin. 


\section{Referensi}

Boediono, Gideon SB. (2005). Kualitas Laba: Studi Pengaruh Mekanisme Corporate Governance dan Dampak Manajemen Laba dengan Menggunakan Analisis Jalur. Simposium Nasional Akuntansi (SNA) VIII Solo.

Chen, X., Harford, J., Li, K. (2007). Monitoring: Which Institusion Matter? Journal Of Financial Economics. 82(2):279-305

Darwis, Herman. (2012). Manajemen Laba Terhadap Nilai Perusahaan Dengan Corporate Governance Sebagai Pemoderasi. Jurnal keuangan dan Perbankan, Vol. 16 No. Hal 45-55

Ferdawati. (2009). Pengaruh Manajemen Laba Rill Terhadap Nilai perusahaan. Jurnal Akuntansi dan Manajemen, Vol 4 No. 1 Juni 2009. Hal 59-47

Haruman, Tendi. (2008). Pengaruh Struktur kepemilikan Terhadap Keputusan Keuangan dan Nilai Perusahaan Survey Pada Perusahaan Manufaktur di PT. BEI. Simposium Nasional Akuntansi XI. Pontianak

Herawaty, Vonola. (2008). Peran Praktek Corporate Governance sebagai Moderating Variable dan Pengaruh Earnings Management Terhadap Nilai Perusahaan. Jurnal Akuntansi dan Keuangan, Vol 10 No. 2 Hal. 97-108

Herdiyanto, Dedy Ghozim. Dan Moh. Didik Aryanto. (2015). Pengaruh Tax Avoidance Terhadap Nilai Perusahaan. Diponegoro Journal Of Accounting. Volume 4, Nomor 3 Hal. 1-10

Jensen, M.C and Meckling, W.H. (1976). "Theory of Firm: Managerial Behaviour, Agency Cost and Ownership Structure". Journal of Financial Economics. 3. pp. 305-360.

Kawatu, Freddy Samuel, (2009). Mekanisme Corporate Governance Terhadap Nilai Perusahaan Dengan Kualitas Laba Sebagai Variabel Intervening, Fakultas Ekonomi-Universitas Negeri Manado Tondano.

Kusumayani, Happy Aspari dan Ketut Alit Suardana. (2017). Kepemilikan Manajerial dan Kepemilikan Institusional Sebagai Pemoderasi Pengaruh Perencanaan Pajak Terhadap Nilai Perusahaan. E-Jurnal Akuntansi Universitas udayana Vol. 18.1

Latan, Hengky. Imam Ghozali, (2014). Partial Least Squares Konsep, Metode Dan Aplikasi Menggunakan Program Warppls 2.0. Badan Penerbit UNDIP

Lestari, Nanik dan Selvy Agita Ningrum. (2018). Pengaruh Manajemen Laba Dan Tax Avoidance Terhadap Nilai Perusahaan Dengan Kualitas Audit Sebagai Variable Moderasi. Journal of Applied Accounting And Taxation Vol. 3 No. 1 March 2018 Hal. 99-109

Mawati, Eny Rufiyad, dkk. (2017). Corporate Governance Memoderasi Earnings Management dan Profitabilitas Terhadap Nilai perusahaan. Prosiding Seminar Nasional Multi Disiplin Ilmu \& Call For Papers Unisbank Ke-3 (SENDI_U 3) ISBN:9-789-7936-499-93

Nurlela, R., \& Islahuddin. (2008). Pengaruh Corporate Social Responsibility Terhadap Nilai Perusahaan Dengan Prosentase Kepemilikan Sebagai Variabel Moderating. Pontianak: Simposium Nasinal Akuntasi XI

Pamungkas, Dyas Tri. (2012). Pengaruh Earnings Management Terhadap Nilai Perusahaan Dengan Corporate Governance Sebagai Variabel Pemoderasi. Semarang: Skripsi Universitas Diponegoro 
Purwaningtyas, Frysa Praditha. (2011). Analisis Pengaruh Mekanisme Good Corporate Governance Terhadap Nilai Perusahaan (Studi Empiris Pada Perusahaan Manufaktur yang Terdapat di BEI Tahun 2007-2009). Semarang: Skripsi Mahasiswa Universitas Diponegoro

Ratnawati, Vince,. Mohammad Ali Abdul-Hamid, dan Oluwatoyin Muse Johnson Popoola. (2015). The Influence og Agency Conflict Types I and II on Earnings Management. International Journal of Economics and Financial Issues. 6 (S4) pp. 126-132

Ratnawati, Vince,. Mohammad Ali Abdul-Hamid, dan Oluwatoyin Muse Johnson Popoola. (2016). The Intraction Effect of Institusional Ownership and Firm Size on the Ralationship between Managerial Ownership Management. International Conference on Accounting Studies (ICAS). 15-18 Agustus 2016, Malaysia

Riahi, Ahmed dan Belkaoi. (2012). Teori Akuntansi: Edisi Kelima. Jakarta: Salemba Empat

Sartika, Dewi dan Fidiana. (2015). Moderasi Kepemilikan Institusional Terhadap Hubungan Perencanaan Pajak Dengan Nilai Perusahaan. Jurnal Ilmu Dan Riset Akutansi. Vol. 4 No. 12

Setiyaningsih. (2018). Peran Kepemilikan Institusinal dan Transparansi Perusahaan Sebagai Variabel Pemoderasi Pada Hubungan Penghindaran Pajak Dengan Nilai Perusahaan. Accounting Global Journal Vol.2 No.1 Oktober 2018 hal 49-63

Subramayam, KR. Dan John J. Wild. (2010). Analisis Laporan Keuangan, Buku Satu, Edisi Sepuluh. Jakarta: Salemba Empat

Sudiyatno, Bambang dan Elen Puspitasari. (2010). Pengaruh Kebijakan Perusahaan Terhadap Nilai Perusahaan Dengan Kinerja Perusahaan Sebagai Variabel Intervening (Studi Pada Perusahaan Manufaktur Di Bursa Efek Indonesia). Dinamika Keuangan dan Perbankan, Mei 2010 Hal. 1-22 ISSN:1979-4878

Sujoko dan Soebiantoro, U. (2007). Pengaruh Struktur Kepemilikan Saham, Leverage, Faktor Intern dan Faktor Ekstern Terhadap Nilai Perusahaan. Jurnal Manajemen dan Kewirausahaan. Vol 9, No. 47

Sukirni, Dwi. (2012). Kepemilikan Manajerial, Kepemilikan Institusional, Kebijakan Dividen dan Kebijakan Hutang Analisis terhadap Nilai Perusahaan. Accounting Analysis Journal. Vol. 1, No. 2, hal: 1-12,

Wahyudiono, Bambang. (2014). Mudah Membaca Laporan Keuangan. Raih Asa Sukses: Jakarta.

Wardhani, Ratna. (2008). Mekanisme Corporate Governance Dalam Perusahaan Yang Mengalami Masalah Keuangan (Financial Distressed Firm). Simposium Nasional Akuntansi X, Makasar. 26-28 Juli 2007

Yuono, Citra Ayuning Sari dan Dini Widyawati. (2016). Pengaruh Perencanaan Pajak dan Corporate Governance Terhadap Nilai Perusahaan. Jurnal Ilmu dan Riset Akuntansi, Vol. 5 No. 6 Juni 2016 